MH EK Védelem Egészségügyi Központ

\title{
Van-e élet az (él)sport után?
}

\author{
Dr. Györfy Ágnes PhD
}

\section{Kulcsszavak: sportpszichológia, versenysport abbahagyás}

A versenysport, élsport abbahagyása számos jelentős változással jár a sportoló életében, testi, lelki, szellemi szinten egyaránt. A test esetében leáll a fokozott igénybevétel, más jellegü terhelés következik, aminek hatására számos, addig elnyomott, a cél miatt háttérbe szorított egészségügyi probléma is előtérbe kerülhet, ami a korábbi szigorú ellenőrzés nélkül, akár halálos kimenetelü is lehet. Lelki szinten sok sportoló számára olyan nehéz a teljes életmód megváltozása, hogy a megküzdés szintjén gyakran szélsőséges megoldások jelennek meg, mint a késői rendszeres újrakezdés, a sporttól való teljes eltávolodás, még nézése sem fér bele lelkileg az egyén számára vagy egészségügyi veszélyeztetettség esetén sem hagyható abba, a halál is elfogadhatóbb a vereségként megélt abbahagyásnál. Szellemi szinten megjelenhet a céltalanság, a jövőkép kilátástalansága, a hogyan tovább kérdésre a válasz keresése, egyes esetekben akár öngyilkossági szándék vagy kísérlet is felmerülhet. Éppen ezért kulcsfontosságú, hogy a sportolót ebben a helykeresési folyamatban segítsük, $s$ ennek révén új szerepben, új életmóddal és szemlélettel mások életét is gazdagíthatja, sajátjában pedig megélheti, nemcsak teljesítménye révén értékes, hanem mint ember is. Sok esetben lehet megoldás az edzői pálya mentén a sport részleges továbbvitele vagy a személyes példamutatás révén a sportolói karrier és az egészséges életmód, mozgás fontosságának hangsúlyozása a társadalom más tagjai felé. 
$\mathrm{Az}$ élsport, versenysport egyfajta életmód, életpálya, hivatás, ily módon annak abbahagyása az egyén életének egészét érinti. Abbahagyása révén megváltozik minden, testi, lelki, szellemi szinten egyaránt. Ezen szintek egyenként történő vizsgálatánál a következő figyelmet érdemlő változásokat tapasztalhatjuk:

\section{Testi szintü változások}

A leállás egyfajta hirtelen tempóváltás, amelyhez fiziológiai szempontból is alkalmazkodni kell. Változhat ezzel együtt a bioritmus, a cirkadián ritmus és az anyagcsere is, amelyek a mindennapi müködés fontos elemei, s meghatározó szereppel bírnak a testi-lelki jól-lét szempontjából. A versenyzés miatt korábban kezelt és elfogadott, a fokozott terhelésből adódó egészségügyi problémák elötérbe kerülnek, s hangsúlyuk, szerepük más lesz a versenyzés adta értelmezési keret megszűntével. A tempóváltás a terhelés jellegének megváltozásával számos új kardiovaszkuláris problémát is felvethet, esetenként akár letális következményekkel, hirtelen szívhalállal [1]. Az anyagcserével a testsúly is változik, ami a testképet is befolyásolja, gyakran jelenik meg kisebb vagy nagyobb mértékü elhízás.

A terhelés változásával változik a stresszre adott fiziológiai válaszban szerepet játszó kortizol szintje és szabályozása, akárcsak a koleszteriné [2], amelyek a mindennapi feszültség és terhelés kezelését, lereagálását is befolyásolja. Ennek egyensúlya nagyon lassan, nehezen változik, fóleg a koragyermekkorban elkezdett és az élettartam egy késői szakaszáig vitt sportolói karrier esetében.

\section{Lelki szintű változások}

Lelki szinten az egyénre kevesebb figyelem irányul, amely az önértékelést is nagymértékben befolyásolja, hiszen, ha nem figyelnek rám, nem vagyok fontos, szerethető, értékes. Mindenki számára a megszokott mértékü, személye iránti érdeklődés jelenti az alapot. Az élsportolók esetében a gyermekkortól jelenlévő fokozott odafigyelés még nagyobb intenzitással épül be.

A versenysport célt ad, újabb verseny, újabb kihívás, még messzebb, még tovább, még távolabbra, még jobban. Abbahagyásával ez a cél megszűnik, s nincs rutin arra vonatkozóan, mi van azután, ritkán van, lehet más, ami ennyire kitölt időt, teret és ennyi energiát igényel az egyéntől. Szinte egyik pillanatról a másikra céltalanság, légüres tér veheti körbe a volt sportolót. Gyakran megjelenhet kezdetben, az hogy csak a terhet, a folyamatos nyomást szeretné letenni, attól akar megválni, de nincs stabil, reális jövőképe.

Fontos kérdésként merül fel: miképp boldogul az élet más területein, más szerepeiben. Van-e párkapcsolat, család, megjelenik-e a szülöi szerep, ha igen, mennyiben változik a korábbihoz képest több elérhetőséggel, aktívabb részvétel lehetőségével. Abban az esetben, ha nem, hogyan lehetséges ennek, ezeknek a szerepeknek a kialakítása? A sportolói szerep a legtöbb esetben egyfajta öndefiníció is: sportoló vagyok. Ilyenkor sokkal nehezebb a korábbi szerephez való visszatalálás, hiszen a leggyakrabban gyermekkori az azoktól való eltávolodás, ami az összes szociális szerepre hatással lesz. A baráti kör is ebből adódóan sportolói és ez tovább növeli a kör zártságát. A társalgás fonalának felvétele szintén nehézkes lehet, hiszen a civil, nem spor- 
tolói körrel nincs élményközösség, közös téma. A sport pedig kitölti az időt és az életet, így pótlása is nehézségekbe ütközhet, erőfeszítést igényelhet.

A beállítódásban szinte törvényszerüen kialakul egy erős teljesítményorientáció. A teljesítmény része lesz az önmeghatározásnak. A sportoló részéről: „az vagyok, aki jól teljesít, aki ennek révén kiemelkedik". Mindez implikálja, „ha nem tudom hozni a megfelelő színvonalat, teljesítményt, akkor az értékem is megkérdőjelezhetővé válik, akárcsak a fontosságom, hasznosságom”. Az egyén már gyermekként folyamatosan ebben kap megerősítést, erre kap visszajelzést. Tanulási folyamat szükséges ahhoz, hogy a későbbiekben ez a meghatározás tágabb és megengedőbb legyen.

\section{Szellemi szintü változások}

Szellemi szinten az merül fel: mi határozza meg a gondolkodást, ha az, ami korábban kitöltötte, kiesik? Mi történik a szűkebb és tágabb szociális környezettel, ha ez a burok megszünik, ez a zárt világ részben vagy egészben elenged? Az effajta zártság, évtizedekig fennállhat, ami akár végleges izolációt, kívülállást eredményezhet a szociális környezetből. Az idő strukturálása is megváltozik, a korábbi szigorú napirend időbeosztás kevésbé lesz kötött, mind napi, heti, éves szinten. Lesz egyféle fellazulás és légüres tér ebböl a szempontból, amit meg kell tölteni, mert a teljesítményorientációval együtt a struktúraigény is jelen lesz, tartósan beépülve az egyén életébe. Mi lesz az egyén életében, ami kitölti ezt az időt és teret, mi lesz az érdeklődés új területe, ami ha nem is ilyen mértékben, mint korábban a sport, de testi-lelki-szellemi szinten egyaránt megadja azt, amit a korábbi sportolói pálya? Erre a kérdésre kulcsfontosságú választ találnia a korábbi élsportolónak.

\section{Megküzdési kísérletek}

Az abbahagyást követően a korábbi élsportolónak meg kell küzdenie ezen változásokkal. E megküzdési kísérletek pozitív és negatív irányt egyaránt vehetnek. A negatív irány esetén akár az a választás is megszülethet. Amikor nincs jövőkép, nincs terv az azutánra, a megváltozott élethelyzet vállalhatatlan. Számos neves sportoló vonatkozásában újságcikk, szalagcím számolt be ilyen szituációról, ahol az okot firtatták, illetve közvetve rávilágítottak az időben történő jövőkép kialakításnak fontosságára.

A probléma megjelenhet, mint egyfajta megküzdési kísérlet, a folyamatos újrakezdés, visszavonulás és újra versenyzés bizonyos váltakozása, ami során a sportoló nehezen engedi el korábbi életformáját, életszakaszát. Kérdésként merül fel, hogy reális-e a saját képességek értékelése vagy megmarad egy korábbi müködési nívónál, nem követve a változásokat. A zárást követően szintén egyfajta megküzdési kísérletként értelmezhető a sport teljes elutasítása, amiben esetenként akár annak nézése, megtekintése sem vállalható.

Pozitív megküzdési kísérlet, gyakran sikeres és egyben a leggyakoribb választás a sport közelében maradás, a sport beépítése a mindennapi életbe más formában, mint a korábbiakban. Ennek egyik változata az edzői szerep, ahol újabb generációknak adható át a hasznosítható tudás a sportról, illetve megélhető a saját hasznosság. Gyakori választás a sport, az egészséges életmód népszerüsítése a médiában, illetve más fórumokon, amely- 
ben a korábbi ismert, szereplést megszokott élsportoló különösen hiteles tud lenni. Ez személyes példamutatás is egyben, ami utólagosan megerősíti a pálya értékét az egyén és közössége életében. Hasznos, kreatív feldolgozási forma minden olyan pálya választása, amiben fontos szerepe van az erőnlétnek, a kitartásnak, a feladattudatnak és a sportnak, akár a katonai vagy a rendöri pálya esetében.

\section{A pszichológiai tanácsadás, kísérés kérdései}

Amennyiben szakember segíti a sportolót az abbahagyás, váltás szakaszában vagy azt követően, az esetleges elakadások szempontjából a következő tényezőkre fontos figyelmet fordítania:

$\mathrm{Az}$ abbahagyás egy gyászfolyamatot [3] indít el, amiben számos elakadás lehetséges. A tanácsadás folyamatában, ebben a gyászban, leválásban, elengedésben igyekszünk segíteni, az esetleges elakadásokat feloldani, elősegíteni egy stabil terv, jövőkép kialakítását.

Mi az abbahagyás, a sportolói karrier befejezésének az oka? Személyes döntés vagy egyfajta kényszerből fakad (pl: testi állapot, sérülés) Az utóbbi esetben sokkal nehezebb a leválás, a pálya gyászfolyamata, mint tudatos, felkészült döntés eredményeképpen. Ezért célszerü erre felkészülni [4].

Személyes szinten mi a legfontosabb a sportban? Ennek tisztázása azért fontos, mert a személyes kötődés, részelem, momentum továbbvihető az egyén életében, akár új életpályájában, foglalkozásában, illetve ennek továbbvitele megkönynyíti a leválást, átállást.

Ebben a tanácsadási folyamatban az egyén világos, stabil és realisztikus jövőképét igyekszünk támogatni. Legyen gyakorlatias, kidolgozott, vállalható és vonzó az individuum számára, amit tartósan, elköteleződéssel tud vinni. Legyenek mellette jó alternatívák, esetleg több út, ami érzelmileg is és nemcsak a feladat, az aktivitás szintjén jár bevonódással.

Fontos a környezet szerepe: mennyire támogató az egyénnel szemben, mennyire segítik váltását, helykeresését, átállását élete új szakaszában, sportolói karrierje zárásában? Mennyire elfogadott és elfogadható az új szerepben, s mennyire van jelen a korábbi identitás? Ez utóbbi milyen mértékben megerősítő, illetve mennyire zavaró jellegü?

Összegezve: a sportolói karrier zárása nehéz helyzetet teremt, változást indukál, ami az egyént testi-lelki-szellemi szinten egyaránt érinti. A zárás gyászfolyamattal jár, ami egyéni jellegzetességeket mutat és számos elakadás lehetőségét rejti magában. Azonban tervezhetö, lehetséges rá a felkészülés és a támogatás is biztosítható ebben. A stabil jövőképpel rendelkező sportoló tudása átadásával a közösséget gazdagítja, továbbá saját életét is örömteli módon viheti tovább.

\section{Irodalom}

[1] Jákó P.: Sport, egészség, társadalom. Magyar Tudomány. 2012. 1081-1089.

http://www.matud.iif.hu/2012/09/07.html

[2] Tsopanakis, A., Stalikas, A., Sgouraki, E., Tsopanakis, C: Stress adaptation in athletes: Relation of lipoprotein levels to hormonal response. Pharmacology Biochemistry and Behavior, 1994, 48: 377-382.

DOI: 10.1016/0091-3057(94)90541-X.

[3] Kast V.: A gyász - Egy lelki folyamat stádiumai és esélyei. Park kiadó, 2009, Budapest

[4] Gyömbér N., Kovács K.: Fejben dől el. Kossuth Kiadó, 2013, Budapest 


\section{Ágnes Györfy PhD}

\section{Is there life after being a sport professional?}

Quitting professional sport has its serious consequences, on physical, psychical and mental level either. It involves a lot of changes. On body level the extreme burden stops and as a consequence several formerly hidden or suppressed symptoms, health problems can come forward and in extreme cases can have lethal endings. On the psychological level it is so hard for the athletes to change the whole life style that on the level of coping extreme solutions will appear such as: returning to compete several times at older age, quitting sport totally even avoiding to see it or dying because of burden in case of quitting from health causes is more acceptable than quitting professional sport. On mental level we could see aimlessness, the futureless aspect or the search for the answer to the where to go further question in extreme cases even suicidal thoughts or attempts can even occur. Because of this it is extremely important to support the athletes in this process of finding one's place in order that he in his new part of his life can enrich others' with his lifestyle and sport promoting aspect. The athlete can have the experience that he is a valuable as a person and not just for his performance. In several cases it's a good solution to bring the sport - sport life along through the coach carrier or to promote the importance of sporty lifestyle, healthy lifestyle to the other members of the community on different social forums.

Key-words: sportpsychology, professional sport, quitting professional sport

Dr. Györfy Ágnes PhD 1134 Budapest, Róbert Károly krt. 44. 